\title{
Detection of different types of papillomavirus and co-infection in cattle in the State of
}

\section{Goiás - Brazil}

\author{
Deteç̧ão de diferentes tipos de papiloma vírus e coinfecção em bovinos no Estadlo de Goiás- Brasill \\ Detección de diferentes tipos de papilomavirus y coinfección en bovinos del Estado de Goiás- Brasil
}

\begin{abstract}
Bovine papilomavírus (BPVs) is the etiological agent of bovine papillomatosis, a disease that triggers warts throughout the skin, udder, roofs, genitalia and in more severe cases can develop extensive papillomas, cause neoplasia in the digestive tract and bladder, cause losses in productivity and losses to livestock. In Brazil, the occurrence of BPV infection is relatively common, but the identification of viral types is still sporadic. The present study is a research report that aimed to describe the occurrence of BPV infections in dairy cattle affected by papillomatosis, based on the nucleotide sequences of the ORF L1, the most conserved sequence. Twenty-five samples of cutaneous wart from nine cattle clinically diagnosed as cutaneous papillomatosis were analyzed in the state of Goiás, central-western Brazil. Amplification was obtained in 11 samples (papilloma) from different cattle. PCR reactions followed by sequencing revealed the presence of BPV-1 in 60\%, BPV-5 in 40\%, and BPV-14 in $20 \%$ of the samples analyzed. The presence of coinfection was verified in $60 \%$ of the amplified samples. These data suggest that several types of BPV can infect a lesion simultaneously and demonstrate the possibility that BPV infection in epithelial tissue can occur without restriction to one or two viral types, demonstrating the region's genetic diversity. As far as we know, this is the first registry of typification of BPVs of the central-western region of Brazil. This analysis provides important information for bovine papillomavirus (BPV) research in Brazil.
\end{abstract}

Keywords: Animal health; Bovine papilloma; Bovine cattle; Infected cattle.

\section{Resumo}

O papilomavírus bovino (BPVs) é o agente etiológico da papilomatose bovina, doença que desencadeia verrugas por toda a pele, úbere, teto, genitália e em casos mais graves pode desenvolver papilomas extensos, causar neoplasia no trato digestivo e bexiga, causar prejuízos na produtividade e perdas para o gado. No Brasil, a ocorrência de infecção pelo BPV é relativamente comum, mas a identificação dos tipos virais ainda é esporádica. O presente estudo, é um relatorio de pesquisa que teve como objetivo descrever a ocorrência de infecções por BPV em bovinos leiteiros acometidos por papilomatose, com base nas sequências de nucleotídeos da ORF L1, a sequência mais conservada. 
Vinte e cinco amostras de verrugas cutâneas de nove bovinos com diagnóstico clínico de papilomatose cutânea foram analisadas no estado de Goiás, centro-oeste do Brasil. A amplificação foi obtida em 11 amostras (papiloma) de diferentes bovinos. As reações de PCR seguidas de sequenciamento revelaram a presença de BPV-1 em 60\%, BPV-5 em $40 \%$ e BPV-14 em $20 \%$ das amostras analisadas. A presença de coinfecção foi verificada em $60 \%$ das amostras amplificadas. Esses dados sugerem que vários tipos de BPV podem infectar uma lesão simultaneamente e demonstram a possibilidade de que a infecção do BPV em tecido epitelial possa ocorrer sem restrição a um ou dois tipos virais, demonstrando a diversidade genética da região. Pelo que sabemos, este é o primeiro registro de tipificação de BPVs da região centro-oeste do Brasil. Esta análise fornece informações importantes para a pesquisa do papilomavírus bovino (BPV) no Brasil.

Palavras-chave: Saúde animal; Papiloma bovino; Gado bovino; Gado infectado.

\section{Resumen}

El papilomavirus bovino (BPVs) es el agente etiológico de la papilomatosis bovina, una enfermedad que desencadena verrugas en toda la piel, ubres, techos, genitales y en casos más severos puede desarrollar papilomas extensos, causar neoplasias en el tracto digestivo y vejiga, ocasionar pérdidas de productividad. y pérdidas de ganado. En Brasil, la aparición de la infección por BPV es relativamente común, pero la identificación de tipos virales aún es esporádica. El presente estudio es un informe de investigación que tuvo como objetivo describir la ocurrencia de infecciones por VBP en ganado lechero afectado por papilomatosis, a partir de las secuencias de nucleótidos del ORF L1, la secuencia más conservada. Se analizaron 25 muestras de verrugas cutáneas de nueve bovinos diagnosticados clínicamente como papilomatosis cutánea en el estado de Goiás, centro-oeste de Brasil. La amplificación se obtuvo en 11 muestras (papiloma) de diferentes bovinos. Las reacciones de PCR seguidas de secuenciación revelaron la presencia de BPV-1 en el 60\%, BPV-5 en el $40 \%$ y BPV-14 en el $20 \%$ de las muestras analizadas. Se verificó la presencia de coinfección en el $60 \%$ de las muestras amplificadas. Estos datos sugieren que varios tipos de BPV pueden infectar una lesión simultáneamente y demuestran la posibilidad de que la infección por BPV en el tejido epitelial pueda ocurrir sin restricción a uno o dos tipos virales, lo que demuestra la diversidad genética de la región. Hasta donde sabemos, este es el primer registro de tipificación de BPV de la región centro-occidental de Brasil. Este análisis proporciona información importante para la investigación del virus del papiloma bovino (VBP) en Brasil.

Palabras clave: Sanidad animal; Papiloma bovino; Ganado bovino; Ganado infectado.

\section{Introduction}

Papillomatosis is an infectious disease which has the etiologic agent papilloma virus (PV), characterized by the presence of hyperproliferative lesions (papillomas), which can progress to malignancy (Daudt et al., 2018). The bovine papilloma virus (BPV) is easily disseminated in the herd and to date, there is no vaccine or truly effective treatment against the etiological agent (Módolo et al., 2017). Still, it promotes significant losses in the herd, generating economic loss for the producer and the meat, milk and leather industries (Módolo et al., 2017).

To date of 24 types of BPV have been described in the literature, classified into five genera: Delta-papillomavirus (BPV-1, 2, 13 e 14), Epsilon-papillomavirus (BPV-5 e 8), Xi-papillomavirus (BPV-3, 4, 6, 9, 10, 11, 12, 15, 17, 20, 23, 24), Dyoxi-papillomavirus (7), Dyokappa-papilomavirus (BPV-16 e 22) e BPV-18, BPV-19 and BPV-21 that do not yet belong to any gender (Daudt et al., 2018a, 2018b).

The PVs are strictly species-specific, even under experimental conditions, not infecting a host other than the natural one. The only ones known to promote interspecies cross infection are the Deltapapillomaviruses, which raises the question of how this viral type can overcome the interspecies barriers (Roperto et al., 2018).

In horses, the delta papillomavirus $(\delta \mathrm{PV})$ is associated with lesions known as sarcoids, characterized by fibroblast proliferation and hyperplasia or dysplasia (Nasir \& Brandt, 2013). These types of injury are aggressive, rarely regress and often recur after therapy (Lunardi et al., 2013). It is notable that $\delta$ PV 14 infection has been related to similar feline lesions (Munday et al., 2015).

The $\delta$ PVs were also observed in cutaneous fibropapillomas and buffalo bladder tumors (Roperto et al., 2013). Bovine SPVs are thought to cause cutaneous sarcoids in African lions (Orbel et al., 2010), domestic cats (Munday et al., 2015), cape mountain zebras, giraffes and sable antelope (Williams, 2011). The types of bovine $\delta$ PVs were also detected clinically in normal skin samples from many wild non-bovine ruminants (Savini, 2016) and in peripheral blood samples from sheep 
(Roperto et al., 2018).

The identification of viral types in the region and their prevalence are necessary to characterize the epidemiology of circulating viral types, which once identified, allows directing the development of containment and prophylactic measures (Claus et al., 2009). The association of BPV 14 with aggressive lesions and interspecies infection calls attention in a scenario with lack of information of its prevalence.

Aiming at this, the present study aimed to identify BPVs found in cattle herds in the State of Goiás - Brazil, this study represents the first case of BPV 14 in the State of Goiás, aiming to contribute to the knowledge of the diversity of PVs that affect the animals and to the generation of effective prophylactic or therapeutic vaccines.

\section{Methodology}

In this article was used the methodology according Koche (2011).

\subsection{Collection of samples}

The cattle selected for the study came from beef and dairy farms in Midwest Brazil where cutaneous papilomatosis occurs. We examined a total of 9 animals male and female Girolanda cattle, aged 9- 24 months, in the city of Goiânia - Goiás, Brazil. The lesions were variously located on the head, nose or around the eyes and dispersed around the body. Multiple samples were obtained from animals with several skin lesions to assess co-infection, resulting in the collection of 25 cutaneous lesions, clinically classified as cauliflower, flat and peduncle. These were obtained from different anatomical parts of the animal.

The collection was characterized by the tricotomy around the papillomas, with 10\% iodine asepsis at the anesthetized site, using Lidocaine hydrochloride and Epinephrine, and then the papillomas were removed and stored in a falcon tube and identified with the cattle number and location. papilloma. The excision site was sutured, and 10\% iodine was applied over the lesion. All procedures were performed according to the Ethics Committee on the Use of Animals of the Federal University of Goias (Protocol Number 049-14).

\subsection{Extraction of Nucleic Acid}

DNA extraction from bovine tissue samples was performed according to the Genomic DNA Purification kit protocol (Wizard, Promega Corporation, USA). DNA quality was verified by PCR of the bovine $\beta$-globin gene, as described by Freitas et al. (2003).

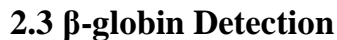

Each DNA sample was tested for identification of the bovine $\beta$-globin protein, with the Forward oligonucleotides: 5 'AACCTCTTTGTTCACAACCAG-3' and Reverse 5'-CAGATGCTTAACCCACTGAGG- 3' which amplifies a fragment of 450pb. The PCR reaction was performed according to the protocol of the 2x PCR-Mix LGC Biotechnology kit ${ }^{\circ}$ (Labtrade \& LGCBio, Brasil). All data related to the PCR reaction and parameters for amplification of the oligonucleotides for $\beta$-globin are summarized in Table 1 and Table 2. $\beta$-globin was used to check the quality of the extracted DNA (Freitas et al., 2003). 
Table 1. PCR reaction for $\beta$-globin.

\begin{tabular}{cc}
\hline Volume & Reagent \\
\hline $\mathbf{1 0} \mathbf{n g} *$ & DNA \\
$\mathbf{2 , 5} \boldsymbol{\mu L}$ & Buffer 10X PCR $\left(\mathrm{Mg}^{2+}\right.$ Free $)$ \\
$\mathbf{3 , 0} \boldsymbol{\mu L}$ & $\mathrm{MgCl} 2$ \\
$\mathbf{0 , 5} \boldsymbol{\mu} \mathbf{L}(\mathbf{1 0 0} \mathbf{m M})$ & dNTP \\
$\mathbf{1 , 0} \boldsymbol{\mu L}$ & Oligonucleotides Forward \\
$\mathbf{1 , 0} \boldsymbol{\mu} \mathbf{L}$ & Oligonucleotides Reverse \\
$\mathbf{0 , 2 5} \boldsymbol{\mu} \mathbf{L}(\mathbf{5} \mathbf{U} / \boldsymbol{\mu L})$ & DNA Taq polymerase \\
$* *$ enough to & Deionized water \\
$\mathbf{2 5} \boldsymbol{\mu} \mathbf{L}$ & End Volume \\
\hline
\end{tabular}

* The amount of DNA included in the reaction was calculated individually, according to the concentration of each sample. ** Deionized water was used to complete the final volume of the reaction. Source: Authors.

Table 2. Parameters for amplification of bovine $\beta$-globin oligonucleotides.

\begin{tabular}{ccc}
\hline & \multicolumn{2}{c}{$\beta$-globin bovine } \\
\cline { 2 - 3 } Time & Temperature $\left({ }^{\circ} \mathbf{C}\right)$ \\
\hline Start & 2 minutes & $96^{\circ}$ \\
Denaturation & 1 minute & $94^{\circ}$ \\
Ringing & 2 minutes & $55^{\circ}$ \\
Extension & 1 minute & $72^{\circ}$ \\
& & 40 cicles \\
Final Extension & 7 minutes & $72^{\circ}$ \\
\hline
\end{tabular}

Source: Authors.

\subsection{PCR assay}

To identify the viral type of bovine Papillomavirus, we used sets of oligonucleotides designed to amplify specific L1 genes of each viral type deposited in the database of the NCBI (Bpap1F, Bpap1R / Bpap2F, Bpap2R / Bpap3F, Bpap3R / Bpap4F, Bpap4R / Bpap5F, Bpap5R / Bpap6F, Bpap6R /Bpap7F, Bpap7R / Bpap8F, Bpap8R / Bpap9F, Bpap9R / Bpap10F, Bpap10R / Bpap11F, Bpap11R / BOV12F, BOV12R / Bpap13F, Bpap13R / Bpap14F, Bpap14R) (Table 3). The PCR reaction was performed according to the protocol of the 2x PCR-Mix LGC Biotechnology ${ }^{\circledR}$ (Labtrade \& LGCBio, Brazil), the primers were previously tested for cross-amplification according to protocol of Silva et al. (2011), in each assay were tested up to five samples to avoid contamination. We subjected $3 \mu \mathrm{l}$ DNA to thermocycling in a $25 \mu \mathrm{l}$ reaction mixture containing $2.5 \mathrm{U}$ Taq DNA Polymerase, $3.5 \mathrm{mM}$ dNTP mix, 10 pmol of each primer, $1.5 \mathrm{mM} \mathrm{MgCl}$, and 10X PCR buffer. Thermal cycling conditions were denaturation for $10 \mathrm{~min}$ at $96^{\circ} \mathrm{C}$, then $50 \mathrm{sec}$ at $94^{\circ} \mathrm{C}$, followed by $40 \mathrm{cycles}$ of $51^{\circ} \mathrm{C}$ for $55 \mathrm{sec}$, and $50 \mathrm{sec}$ at $72^{\circ} \mathrm{C}$. In addition, the reaction tubes were kept for a further $10 \mathrm{~min}$ at $72^{\circ} \mathrm{C}$ for final extensions (Roperto et al., 2018). PCR amplified DNA samples were analyzed by $1 \%(\mathrm{w} / \mathrm{v})$ agarose gel electrophoresis, dissolved in 1x TAE and stained with ethidium bromide $(0.2 \mu \mathrm{g} / \mathrm{ml})$. After the electrophoresis process, the DNA bands were visualized under low intensity ultraviolet irradiation. 
Table 3. Oligonucleotides used for amplification of the $\mathrm{L} 1$ region of the different bovine Papillomavirus viral types.

\begin{tabular}{|c|c|c|c|c|c|}
\hline Viral type & & & Oligonucleotides & $\begin{array}{l}\text { Fragment size } \\
\text { (bp) }\end{array}$ & $\begin{array}{l}\text { Access number - } \\
\text { BLASTn }\end{array}$ \\
\hline \multirow{2}{*}{ BPV $1^{*}$} & Bpap1 & F & CACACCACTCCGAACAG & \multirow{2}{*}{523} & \multirow{2}{*}{ X02346.1 } \\
\hline & Bpap1 & $\mathrm{R}$ & AGAGGCAATACTGCGG & & \\
\hline \multirow{2}{*}{ BPV $2^{*}$} & Bpap2 & $\mathrm{F}$ & TGGAAACGCATTGTC & \multirow{2}{*}{262} & \multirow{2}{*}{ M20219.1 } \\
\hline & Bpap2 & $\mathrm{R}$ & GGGTGGTATAACATACT & & \\
\hline \multirow{2}{*}{ BPV $3^{*}$} & Bpap3 & $\mathrm{F}$ & GACCAACAACAGGGCC & \multirow{2}{*}{192} & \multirow{2}{*}{ AF486184.1 } \\
\hline & Bpap3 & $\mathrm{R}$ & GGACTGCGTAGTACGG & & \\
\hline \multirow{2}{*}{ BPV $4^{*}$} & Bpap4 & $\mathrm{F}$ & GCAGGCACACCTAAAGGCTG & \multirow{2}{*}{505} & \multirow{2}{*}{ X05817.1 } \\
\hline & Bpap4 & $\mathrm{R}$ & GCAGGCACACCTAAAGGCTG & & \\
\hline \multirow{2}{*}{ BPV $5^{*}$} & Bpap5 & $\mathrm{F}$ & GTGCCAAATGGACAGGATATGTGC & \multirow{2}{*}{367} & \multirow{2}{*}{ AF457465.1 } \\
\hline & Bpap5 & $\mathrm{R}$ & GAGACTGACTTACCAAGCCTG & & \\
\hline \multirow{2}{*}{ BPV $6^{*}$} & Bpap6 & $\mathrm{F}$ & GAAGTTGACTGTCCTGCACC & \multirow{2}{*}{390} & \multirow{2}{*}{ AJ620208.1 } \\
\hline & Bpap6 & $\mathrm{R}$ & CGAATGTGCTCTTGGACGGC & & \\
\hline \multirow{2}{*}{ BPV $7^{*}$} & Bpap7 & $\mathrm{F}$ & GGTTCGTGGTATTTGGATGTGG & \multirow{2}{*}{354} & \multirow{2}{*}{ DQ217793.1 } \\
\hline & Bpap7 & $\mathrm{R}$ & CGTGGACGAAACCGACCC & & \\
\hline \multirow{2}{*}{ BPV 8* } & Bpap8 & $\mathrm{F}$ & GCCGCACCGCTGAAGG & \multirow{2}{*}{493} & \multirow{2}{*}{ DQ098913.1 } \\
\hline & Bpap8 & $\mathrm{R}$ & AGTCACTCCACTTGCTCСТCC & & \\
\hline \multirow{2}{*}{ BPV $9^{*}$} & Bpap9 & $\mathrm{F}$ & CAGGGCTGCTATGTATGGGG & \multirow{2}{*}{334} & \multirow{2}{*}{ AB331650.1 } \\
\hline & Bpap9 & $\mathrm{R}$ & CGCCTGTACCATCTATTGCTG & & \\
\hline \multirow{2}{*}{ BPV 10* } & Bpap10 & $\mathrm{F}$ & CTTAGCTCTGATGAATCC & \multirow{2}{*}{591} & \multirow{2}{*}{ AB331651.1 } \\
\hline & Bpap10 & $\mathrm{R}$ & TACTGGTCAAAATATTGCC & & \\
\hline \multirow{2}{*}{ BPV 11* } & Bpap11 & $\mathrm{F}$ & GCAGGTCGGGGGCTGG & \multirow{2}{*}{322} & AB5435071 \\
\hline & Bpap11 & $\mathrm{R}$ & CCAGCCCCCGACCTGC & & \\
\hline pDV 10* & BOV12 & $\mathrm{F}$ & GGTAGCCAGCCTGCAATTAGTG & 528 & IFQ31523 \\
\hline BPV 12 & BOV12 & $\mathrm{R}$ & CAACGAGCTTCTACATTGCCCTG & 528 & JFE \\
\hline BPY 13* & Bpap13 & $\mathrm{F}$ & GCCCAАCСТCTTAAAG & & \\
\hline BPV 13 & Bpap13 & $\mathrm{R}$ & TGCAGGAATCACATTTC & 261 & JQ798171.1 \\
\hline BPV 14 (Munday et & Bpap14 & $\mathrm{F}$ & GGAACAAACCTCACAATCAC & 195 & KR868228.1 \\
\hline al., 2015) & Bpap14 & $\mathrm{R}$ & CCAGTTCTCTAATACTGAGG & 193 & KК 808228.1 \\
\hline
\end{tabular}

Source: Authors.

The material was analyzed by comparison, having as parameter, the size of the molecular marker bands $1 \mathrm{~Kb}$ DNA Ladder promega ${ }^{\circledR}$ (Promega Corporation, USA). Samples amplified with BPV-specific nucleotides were sequenced in order to confirm the results of standard PCR. The sequencing was performed by the company Ludwing Biotecnologia, located in the city of Alvorada - RS, applying Sanger's methodology for sequencing (Sanger \& Coulson, 1975).

\subsection{Sequence alignment and phylogenetic analysis}

The nucleotide sequences were aligned using BioEdit Sequence Alignment Editor software version 7.0.9.0 (Ibis Therapeutics Carlsbad, CA, EUA) and analyzed in the database of the National Center of Biotechnology - NCBI applying the BLAST tool, with the objective of evaluating the identity and similarity between the sequences obtained in this study and those deposited in the NCBI database for correlation of statistical significance (Altschul, 1997).

For phylogenetic proximity analysis, the sequences were aligned with non-redundant homologous nucleotides, obtained from the "GenBank" Database (Table 4). For characterization of each viral type, the gene coding for L1 protein was used. Sequences were chosen where the probability values were below (Evalue -22). Phylogenetic relationships of the partial nucleotide sequences of the viral types found in this study were performed and the phylogenetic trees were constructed through the Neighbor-joining program, a method developed by Saitou and Nei (1978). A later bootstrap analysis was performed to test the reliability of the tree (Felsenstein, 1985). 
Table 4. Viral Types, References and Gene Bank Accession Number of Viral BPV Types.

\begin{tabular}{cc}
\hline Viral type & ID Gene Bank \\
\hline BPV1 & $*$ \\
BPV2 & M20219 \\
BPV3 & AF486184 \\
BPV4 & X05817 \\
BPV5 & $*$ \\
BPV6 & AJ620208 \\
BPV7 & DQ217793 \\
BPV8 & DQ98913 \\
BPV9 & AB331650 \\
BPV10 & AB331651 \\
BPV11 & AB543507 \\
BPV12 & JF834523 \\
BPV13 & JQ798171 \\
BPV14 & $*$ \\
BPV15 & KM983393 \\
BPV16 & KU519391 \\
BPV17 & KU519392 \\
BPV18 & KU519393 \\
BPV19 & KU519394 \\
BPV20 & KH519395 \\
BPV21 & KU519396 \\
BPV22 & KY705374 \\
BPV23 & KX098515 \\
BPV24 & MG602223 \\
\hline
\end{tabular}

* obtained by sequencing Source: Authors.

Trees were constructed by multiple sequence alignments using the ClustalX program (Thompson, 1997). The size of the branches was estimated with 1000 bootstrapped replicates and the percentage of times in all species are indicated as a monophyletic group. The maximum likelihood phylogenetic tree based on the first and second position of the codon was constructed in Jalview (Waterhouse, 2009).

\section{Results}

Only samples from catthle A.2, A.3, A.4, A.6 and A.9 presented $450 \mathrm{bp}$ of amplified product corresponding to the expected sequence of the $\beta$-globin gene confirming the viability of the DNA sample for PCR.

PCR using type-specific primers identified 11 samples positive for BPV DNA obtained from 5 animals. PCR typing revealed the presence of BPV-1 in 60\% (3/5) of the cattle, BPV-5 in 40\% (2/5), BPV-9 in 20\% (1/5), BPV-10 in 20\% (1/5) BPV-12 in 40\% (2/5), BPV-13 in 20\% (1/5) and BPV-14 with 20\% (1/5), resulting in the presence of seven different types of BPV, all agents of epithelial lesions . BPV-1 was found in lesions on the dewlap, neck, and udder; BPV-5 was detected in lesions on the back and udder; BPV-9 was found on the back; BPV-10, 13 and 14 were found in the neck. and, BPV-12 was detected on the back and udder. The presence of more than one viral type infecting the same lesion was verified in three amplified samples: the first one (A.2) identified BPV types 1, 5 and 12; the second (A.3), BPV types 5 and 12 and the third (A.9) type BPV-1, -10, -13 and -14 , totaling 60\% (3/5) coinfection. (Table 5). 
Table 5. Details of molecular typing of the BPV-positive samples

\begin{tabular}{ccccc}
\hline Cattle & $\begin{array}{c}\text { Location of } \\
\text { papillomatosis }\end{array}$ & $\begin{array}{c}\text { GenBank Accession } \\
\text { number }\end{array}$ & $\begin{array}{c}\text { Type Specific } \\
\text { Primer }\end{array}$ & $\begin{array}{c}\text { The total of BPV detected sequence } \\
\text { analysis }\end{array}$ \\
\hline A.2 & Udder & MF045489.1 & Type 1, 5, 12 & 1,5 \\
A.3 & Back & AF457465.1 & Type 5, 12 & 5 \\
A.4 & Dorse & - & Type 9 & - \\
A.6 & Dewlap & MF045489.1 & Type 1 & 1 \\
A.9 & Neck & KR868228.1 & Type 1, 10,13,14 & 1,14 \\
\hline
\end{tabular}

Source: Authors.

To confirm that the amplified DNA was papilloma viral, the amplicons detected by the primers specific were sequenced. This revealed a $92 \%$ identity with the sequences of bovine BPV 1, 94\% identity BPV -5 and $95 \%$ identity with the sequence of BPV 14, deposited in GenBank under accession numbers MF045489.1, AF457465.1, KR868228.1, respectively. Samples obtained with the oligonucleotides for BPVs -9, 10, 12 and 13 were not successful in sequencing (Table 5). As a result, they were not included in phylogenetic analysis.

Phylogeny was also performed between the sequenced viral types for phylogenetic analysis, the CLUSTAL X program was used and type 14 (BPV 14) and 1 (BPV 1) were shown to be phylogenetic, whereas viral type 5 (BPV 5) presented phylogenetic distance (Fig. 1). Viral type 9 (BPV-9) grouped into a separate branch, thus, this type viral is considered phylogenetically distant.

Figure 1 - Maximum Likelihood tree of bovine papillomavirus.

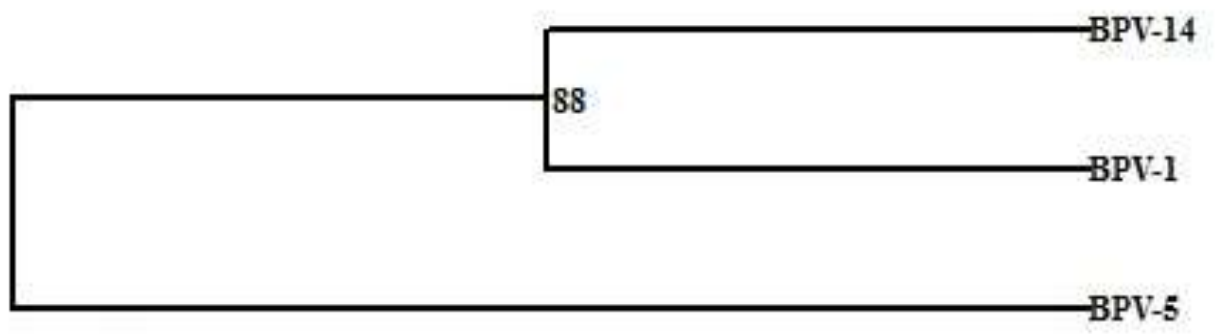

\section{1}

Maximum Likelihood tree of bovine papillomavirus, which comprises 3 BPV types, based on partial sequences of L1 ORF. Two groups of viruses are distinguished, which forms the previously described genera (Deltapapillomavirus and Epsilon papillomavirus). Source: Authors.

To configure the classification of BPV 1, BPV 5 and BPV 14, a survey of the nucleotides of the L1 sequence was carried out and a phylogenetic tree constructed. Fig 2 demonstrates the current arrangement of BPV groups, phylogenetic relationships between all types of papillomavirus established viruses and new types not yet fully characterized. The phylogenetic tree is based on the nucleotide alignment of the L1 (most conserved region of the papillomavirus) sequence for all described types of bovine papillomavirus, where the sequences obtained in the sequencing for BPV 1 , BPV 5 and BPV 14 and the other sequences were obtained from the GenBank database (Table 4). 
Figure 2 - Maximum Likelihood tree of bovine papillomavirus.

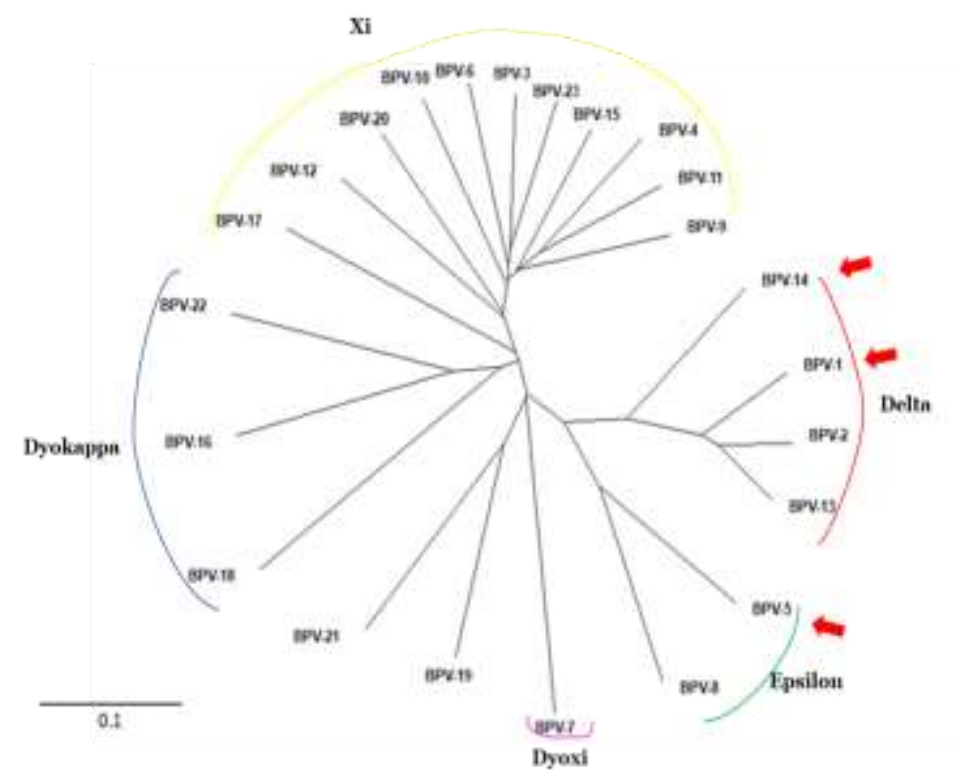

Fig.2. Maximum Likelihood tree of bovine papillomavirus, based on partial sequences of L1 ORF BPVs deposited in GenBank and also by the sequences obtained in sequencing aligned for BPV 1, BPV 5 and BPV 14 (arrows), obtained in this study. Tree generated by the Jalview program (ANDRIEW et al, 2009). The arches delineate the genera of the papillomavirus. The scale bar indicates the genetic distance. Source: Authors.

\section{Discussion}

In the present research, the lesions were classified mainly as cauliflower, the choice of specific oligonucleotides for viral typing aimed at a more accurate viral identification with target gene annealing, since the use of specific primers for the identification of BPV is more sensitive in viral detection than the consensus primers (Silva et al., 2013)

PCR results demonstrated the occurrence of seven viral species present in the pushed cattle (BPV 1, 5, 9, 10, 12, 13 and 14), with the most prevalent BPV 1 present in $60 \%$ of the amplified samples, Batista et al. (2013) relates the high prevalence of BPV 1 with a presence of this viral type in the bovine cutaneous lesion in Brazil. Coinfections were verified in $60 \%$ of the samples with four types of viral lesions, demonstrating a high degree of adaptation of the virus to its host. The occurrence of BPVs $(1,2,6$, and 8) was reported in the northern region of southern Brazil and it was noted that the occurrence of multiple infections does not generate cross-immunity from one viral type to the other and propose that treatment for papillomatosis requires a broad spectrum of coverage to be better (Claus et al., 2009).

Partial sequencing validated the oligonucleotides used for the identification of BPV 1, BPV 5 and BPV 14, representing identity ranging from $92 \%$ to $95 \%$. BPV 1 was the most prevalent, present in $60 \%$ of the amplified samples, related to the high prevalence of this viral type in the cutaneous lesion of bovines in Brazil (da Silva, 2012). Co-infections were verified in $60 \%$ of the samples, demonstrating an adaptation of the virus to its host.

BPV1 and BPV 14 belonging to the Deltapapillomavirus genus and other members of this group may infect both cutaneous and mucosal tissue related to cutaneous neoplastic lesions and feline sarcoids and may possibly be associated with bladder neoplasms such as the other Deltapapillomavirus (BPV 2 and BPV 13), are oncogenic and may cause infections in other species (Roperto et al., 2015, 2016).

The similarity or difference observed in the phylogeny can be attributed to the gender classification of the respective viral types. Viral types 1 and 14 belong to the same genus, the Deltapapillomavirus, demonstrated approximation in branches 14 and 1. The papillomavirus type 5 belongs to the genus Epsilonpapillomavirus, thus justifying the phylogenetic distance between these viral types, verified in the histogram (Fig. 1) (de Villlers et al., 2004). 
Molecular phylogeny data reinforce the idea that certain viral types are quite different between them. Evidence of nucleotide distancing between viral types suggests that there may have been mutations that induced molecular diversity with the capacity to originate 24 viral types. However, it should be noted that although this distancing occurs in the genome, the ORF L1 has similar distribution in all papillomaviruses (de Villlers et al., 2004). This was observed in Fig. 1 and Fig. 2 , confirming this statement.

The ORF L1 of BPV 1 and BPV 14 used in the tree construction suggest the phylogenetic proximity with the other Deltapapillomavirus, BPV type, 2 and 13, which cause typical cutaneous fibropapilloma in bovine (Lunardi, 2013, Munday, 2015) and are commonly associated with interspecies infection (Brandt, 2016; Rector, 2013) as equine and feline sarcoid and BPV 5 L1 ORF showed phylogenetic proximity to BPV 8 also classified as Epsilonpapillomavirus (Savini et al., 2016).

\section{Conclusion}

Despite the high frequency of lesions, BPV genotyping is still sporadic. We emphasize the importance of understanding the diversity and epidemiology of BPV in order to target prevention strategies. Most reports of the prevalence of BPV types are from Brazil and Japan, where Brazil is one of the largest producers of meat and milk in the world and where several types have been described, but as far as we know, this is the first BPV typification record of the Brazilian midwest region. The identification of multiple BPV infections can contribute to the understanding of the epidemiological, clinical and immunological characteristics of papillomatosis in cattle. Additional molecular epidemiological investigations on the incidence and diversity of BPV infection in cattle will help to establishing a more accurate view of the distribution of this virus.

More studies must be carried out to indicate the prevalence of two types of BPV circulating in all of Brazil. Studies associating anatomic region of lesions, macroscopic characteristics and types or genus BPV are important studies to be considered.

\section{Acknowledgments}

My thanks also to the Coordination for the Improvement of Higher Education Personnel (CAPES) and the National Council for Scientific and Technological Development (CNPq).

\section{References}

Altschul, S. (1997). Gapped BLAST and PSI-BLAST: A new generation of protein database search programs. Nucleic Acids Research, 25(17), 3389-3402.

Batista, M. V. A., Silva, M. A. R., Pontes, N. E., Reis, M. C., Corteggio, A., Castro, R. S., Borzacchiello, G., et al. (2013). Molecular epidemiology of bovine papillomatosis and the identification of a putative new virus type in Brazilian cattle. The Veterinary Journal, 197(2), $368-373$.

Brandt, S. (2016). Immune response to bovine papillomavirus type 1 in equine sarcoid. The Veterinary Journal, 216, $107-108$.

Claus, M. P., Lunardi, M., Alfieri, A. A., Otonel, R. A. A., Sartori, D., Fungaro, M. H. P., \& Alfieri, A. F. (2009). Multiple bovine papillomavirus infections associated with cutaneous papillomatosis in brazilian cattle herds. Brazilian Archives of Biology and Technology, 52(spe), 93-98.

Daudt, C., Da Silva, F. R. C., Lunardi, M., Alves, C. B. D. T., Weber, M. N., Cibulski, S. P., Alfieri, A. F., et al. (2018). Papillomaviruses in ruminants: An update. Transboundary and Emerging Diseases, 65(5), 1381-1395.

Daudt, Cíntia, da Silva, F. R. C., Cibulski, S. P., Streck, A. F., Laurie, R. E., Munday, J. S., \& Canal, C. W. (2019). Bovine papillomavirus 24: A novel member of the genus Xipapillomavirus detected in the Amazon region. Archives of Virology, 164(2), 637-641.

Felsenstein, J. (1985). Phylogenies and the comparative method. The American Naturalist, 125(1), 1-15.

Freitas, A. C. de, Carvalho, C. de, Brunner, O., Birgel-Junior, E. H., Dellalibera, A. M. M. P., Benesi, F. J., Gregory, L., et al. (2003). Viral DNA sequences in peripheral blood and vertical transmission of the virus: A discussion about BPV-1. Brazilian Journal of Microbiology, 34, 76-78.

Koche, J.C. (2011). Fundamentos de metodologia científica. Petrópolis: Vozes. 
Lunardi, M., de Alcantara, B. K., Otonel, R. A. A., Rodrigues, W. B., Alfieri, A. F., \& Alfieri, A. A. (2013). Bovine papillomavirus type 13 dna in equine sarcoids. Journal of Clinical Microbiology, 51(7), 2167-2171.

Módolo, D. G., Araldi, R. P., Mazzuchelli-de-Souza, J., Pereira, A., Pimenta, D. C., Zanphorlin, L. M., Beçak, W., et al. (2017). Integrated analysis of recombinant BPV-1 L1 protein for the production of a bovine papillomavirus VLP vaccine. Vaccine, 35(12), 1590-1593.

Munday, J. S., Thomson, N., Dunowska, M., Knight, C. G., Laurie, R. E., \& Hills, S. (2015). Genomic characterisation of the feline sarcoid-associated papillomavirus and proposed classification as Bos taurus papillomavirus type 14. Veterinary Microbiology, 177(3-4), $289-295$.

Nasir, L., \& Brandt, S. (2013). Papillomavirus associated diseases of the horse. Veterinary Microbiology, 167(1-2), 159-167.

Orbell, G. M. B., Young, S., \& Munday, J. S. (2011). Cutaneous sarcoids in captive african lions associated with feline sarcoid-associated papillomavirus infection. Veterinary Pathology, 48(6), 1176-1179.

Rector, A., \& Van Ranst, M. (2013). Animal papillomaviruses. Virology, 445(1-2), 213-223.

Roperto, S., Russo, V., Corrado, F., Munday, J. S., De Falco, F., \& Roperto, F. (2018). Detection of bovine Deltapapillomavirus DNA in peripheral blood of healthy sheep (ovis aries). Transboundary and Emerging Diseases, 65(3), 758-764.

Roperto, S., Russo, V., Leonardi, L., Martano, M., Corrado, F., Riccardi, M. G., \& Roperto, F. (2016). Bovine papillomavirus type 13 expression in the urothelial bladder tumours of cattle. Transboundary and Emerging Diseases, 63(6), 628-634.

Roperto, Sante, Munday, J. S., Corrado, F., Goria, M., \& Roperto, F. (2016). Detection of bovine papillomavirus type 14 DNA sequences in urinary bladder tumors in cattle. Veterinary Microbiology, 190, 1-4.

Roperto, Sante, Russo, V., Ozkul, A., Sepici-Dincel,

A., Maiolino, P., Borzacchiello, G., Marcus, I., et al. (2013). Bovine papillomavirus type 2 infects the urinary bladder of water buffalo (Bubalus bubalis) and plays a crucial role in bubaline urothelial carcinogenesis. Journal of General Virology, 94(2), 403-408.

Saitou, N., \& Nei , M. (1987). The neighbor-joining method: A new method for reconstructing phylogenetic trees. Molecular Biology and Evolution. https://academic.oup.com/mbe/article/4/4/406/1029664/The-neighborjoining-method-a-new-method-for

Sanger, F., \& Coulson, A. R. (1975). A rapid method for determining sequences in DNA by primed synthesis with DNA polymerase. Journal of Molecular Biology, 94(3), 441-448.

Savini, F., Dal Molin, E., Gallina, L., Casà, G., \& Scagliarini, A. (2016). Papillomavirus in healthy skin and mucosa of wild ruminants in the italian alps. Journal of Wildlife Diseases, 52(1), 82.

Silva, M. A. R., Batista, M. V. A., Pontes, N. E., Santos, E. U. D., Coutinho, L. C. A., Castro, R. S., Balbino, V. Q., et al. (2013). Comparison of two PCR strategies for the detection of bovine papillomavirus. Journal of Virological Methods, 192(1-2), 55-58.

da Silva, M. A. R., Carvalho, C. C. R., Coutinho, L. C. A., Reis, M. C., de Aragão Batista, M. V., de Castro, R. S., dos Anjos, F. B. R., et al. (2012). Coinfection of bovine papillomavirus and feline-associated papillomavirus in bovine cutaneous warts: Co-infeccion of bpv and fesarpv. Transboundary and Emerging Diseases, 59(6), 539-543.

Silva, M. A. R., Pontes, N. E., Da Silva, K. M. G., Guerra, M. M. P., \& Freitas, A. C. (2011). Detection of bovine papillomavirus type 2 DNA in commercial frozen semen of bulls (Bos taurus). Animal Reproduction Science, 129(3-4), 146-151.

Thompson, J. (1997). The CLUSTAL_X windows interface: Flexible strategies for multiple sequence alignment aided by quality analysis tools. Nucleic Acids Research, 25(24), 4876-4882.

de Villiers, E.-M., Fauquet, C., Broker, T. R., Bernard, H.-U., \& zur Hausen, H. (2004). Classification of papillomaviruses. Virology, 324(1), $17-27$. Waterhouse, A. M., Procter, J. B., Martin, D. M. A., Clamp, M., \& Barton, G. J. (2009). Jalview Version 2-A multiple sequence alignment editor and analysis workbench. Bioinformatics, 25(9), 1189-1191.

Williams, J. H., Van Dykb, E., Nel, P. J., Lane, E., Van Wilpe, E., Bengis, R. G., De Klerk-Lorist, L.-M., et al. (2011). Pathology and immunohistochemistry of papillomavirus-associated cutaneous lesions in Cape mountain zebra, giraffe, sable antelope and African buffalo in South Africa. Journal of the South African Veterinary Association, 82(2), 97-106. 